\title{
MENGENAL BAHAYA ADIKSI GADGET DAN CARA MENGATASINYA
}

\section{KNOWING THE HAZARD OF GADGET ADDICTION AND HOW TO OVERCOME THEM}

\author{
Mutiara Mirah Yunita ${ }^{1)}$, Teguh Lesmana ${ }^{2)}$, Devi Jatmika ${ }^{3)}$, Alfina Damayanti ${ }^{4)}$, Theresia Finda \\ Kusuma $^{5}$ \\ 1-5)Program Studi Psikologi, Universitas Bunda Mulia \\ Diterima 12 Mei 2021 / Disetujui 28 Mei 2021
}

\begin{abstract}
The use of gadgets is nothing new for teenagers. Through gadgets, teenagers can seek information, connect with friends and seek entertainment. BPS Indonesia stated that the development of cellular phone users in Indonesia increased to around 65.53\% (341.28 million subscribers) in 2019, which previously only reached $38.05 \%$ in 2010. Moreover, during the Covid-19 pandemic, In this regard, the use of gadgets as a means of work and schooling has also increased drastically, both in terms of users and in terms of duration of use. Excessive use of gadgets can cause negative impacts, some of which are stress and symptoms of gadget addiction. Through this service activity, a series of events starts on Friday, April 16, 2021 at 13.00 - 15.00 WIB using the online method via google meet which is divided into three sessions, starting with a brief survey on the use of gadgets by participants, material sessions about gadgets, stress, gadget addiction, and how to deal with the addiction, and finally the question and answer session. The results of this service received a pretty good response and participants experienced an increase in understanding of this gadget addiction. The hope is that the results of this dedication can improve adolescents' understanding of the relationship between stress and gadget use, gadget addiction and how to deal with gadget addiction.
\end{abstract}

Keywords: Pandemic Covid-19, Stress, Gadget Addiction

\begin{abstract}
ABSTRAK
Penggunaan gadget bukanlah hal yang baru bagi remaja. Melalui gadget, remaja bisa mencari informasi, berhubungan dengan teman dan mencari hiburan. BPS Indonesia menyebutkan bahwa perkembangan pengguna telpon seluler di Indonesia meningkat menjadi sekitar 65,53\% (341,28 juta pelanggan) pada tahun 2019 yang mana sebelumnya baru tercapai $38,05 \%$ pada tahun 2010. Terlebih lagi, di masa pandemi Covid-19 saat ini, penggunaan gadget sebagai alat bekerja dan bersekolah, turut meningkat drastis, baik dari sisi pengguna maupun dari sisi durasi pemakaian. Pemakaian gadget berlebihan, bisa menimbulkan dampak negatif, beberapa diantaranya adalah stress dan gejala adiksi gadget. Melalui kegiatan pengabdian ini, rangkaian acara dimulai pada hari Jumat, 16 April 2021 pada pukul 13.00 - 15.00 WIB dengan metode daring via google meet yang dibagi menjadi tiga sesi, dimulai dari survey singkat mengenai penggunaan gadget oleh peserta, sesi materi mengenai gadget, stress, adiksi gadget, dan bagaimana cara mengatasi adiksi tersebut, dan terakhir sesi tanya jawab. Hasil dari pengabdian ini mendapat respon yang cukup baik dan peserta mengalami peningkatan pemahaman mengenai adiksi gadget ini. Adapun harapan dari hasil pengabdian ini dapat meningkatkan pemahaman remaja mengenai hubungan stress dengan penggunaan gadget, adiksi gadget dan cara mengatasi adiksi gadget tersebut.
\end{abstract}

Kata Kunci: Pandemi Covid-19, Stress, Adiksi Gadget.

*Korespondensi Penulis:

E-mail: $\underline{\text { myunita@bundamulia.ac.id }}$ 


\section{PENDAHULUAN}

Sesi awal dimulai dengan melakukan survey singkat pada para peserta mengenai seputar penggunaan gadget yang dilakukan oleh peserta. Pertanyaan seputar aplikasi yang sering kali digunakan, seberapa lama penggunaan gadget, dan sebagainya menjadi informasi bagi kami untuk mengetahui perilaku penggunaan gadget.

Sesi selanjutnya para siswa dijelaskan mengenai dampak penggunaan gadget yang berlebihan terhadap kesehatan mental. Siswa diajak untuk memahami bagaimana penggunaan gadget yang berlebihan dapat mempengaruhi kesehatan mental, ciri-ciri kecanduan gadget, dan strategi untuk mengatasi kecanduan gadget.

Badan Pusat Statistik merilis katalog Statistic Telekomunikasi Indonesia pada tahun 2019. BPS menyebutkan bahwa perkembangan pengguna telpon seluler di Indonesia meningkat menjadi sekitar $65,53 \%$ (341,28 juta pelanggan) pada tahun 2019 yang mana sebelumnya baru tercapai $38,05 \%$ pada tahun 2010. Sedangkan perkembangan kepemilikan komputer di rumah tangga meningkat menjadi sekitar $18,78 \%$ pada tahun 2019 naik jika dibandingkan pada tahun 2012 yang hanya $14,86 \%$.

Penggunaan gadget bukan hal yang baru bagi remaja. Melalui gadget, remaja dapat mengakses internet untuk memperoleh hiburan dengan bermain game, mengakses sosial media, menonton, dan sebagainya. Hal ini di dukung dengan studi yang dilakukan oleh Kominfo bersama dengan UNICEF (2014) yang menyatakan terdapat 3 motivasi utama untuk mengakses internet yaitu untuk mencari informasi, terhubung dengan teman, dan untuk hiburan.

Pandemi Covid-19 juga turut memberikan dampak terhadap perilaku masyarakat dalam menggunakan gadget. Dalam mengontrol persebaran virus Covid-19 pemerintah menerapkan sistem bekerja, belajar, dan beribadah dari rumah sejak bulan April 2020 sehingga tidak menimbulkan kerumunan yang dapat menjadi klaster persebaran Covid-19. Hal ini menyebabkan penggunaan gadget sebagai sarana untuk berkomunikasi sekaligus belajar dan bekerja turut meningkat baik dari segi pengguna maupun dari segi durasi penggunaan.

Penelitian yang dilakukan oleh Amalia \& Hamid (2020) menyatakan adiksi smartphone dapat mempengaruhi kesehatan mental anak dan remaja yang mana paling banyak ditemukan yaitu kecemasan, depresi, dan gangguan perilaku (agresif dan mencederai/membunuh diri). Sedangkan Rini \& Huriah (2020) menyebutkan dampak psikologis dari adiksi gadget ialah depresi, kesepian, gangguan pola tidur, gangguan pemusatan perhatian dan hiperaktif. Tidak hanya itu, adiksi gadget dapat memberikan pengaruh terhadap fisiologis berupa obesitas.

Melihat dampak negative yang ditimbulkan akibat kecanduan gadget maka Pengabdian Kepada Masyarakat ini bermaksud untuk memberikan edukasi kepada remaja bagaimana penggunaan gadget berhubungan dengan stress yang dialami remaja dan bagaimana cara mengatasinya.

Idenfitikasi Masalah dalam penelitian ini terdiri atas dua masalah yakni:

- Meningkatnya jumlah pengguna dan durasi penggunaan gadget terutama pada masa pandemi Covid-19

- Dampak kecanduan gadget terhadap kesehatan fisiologis maupun psikologis

Tujuan pengabdian kepada masyarakat (PKM) ini dilaksanakan adalah untuk meningkatkan kesadaran masyarakat, khususnya kepada siswa SMA yang saat ini sedang belajar online dikarenakan pandemi agar memahami hubungan penggunaan gadget dengan stress dan adiksi gadget. Peneliti berharap, dengan adanya PKM ini, masyarakat lebih memahami gejala-gejala awal adiksi gadget dan mengurangi stress yang ditimbulkan oleh penggunaan gadget terlalu lama.

Setiap kegiatan yang dilakukan diharapkan akan memeberikan manfaat, demikian juga halnya kegiatan pengabdian kepada masyarakat yang diselenggarakan oleh Tim Mahasiswa Fakultas Psikologi Universitas Bunda Mulia ini. Kegiatan 
pengabdian kepada masyarakat ini diharapkan dapat meningkatan kesadaran para siswa/i kelas X dan kelas XI SMA Katolik Santo Petrus Kanisius, Kalimantan Tengah terhadap kecanduan gadget.

\section{TINJAUAN PUSTAKA}

Salah satu alat komunikasi yang paling berkembang pada saat ini adalah gadget, di Indonesia gadget merupakan barang yang hampir dimiliki oleh setiap orang, baik tua dan muda bahkan anak-anak usia pendidikan dasar sudah banyak yang menggunakannya. Peminat gadget di Indonesia bertumbuh sangat pesat ditandai dengan berita yang dikemukakan media bahwa Indonesia termasuk dalam 10 negara pengguna gadget di dunia (Simamora, 2016). Gadget adalah sebuah istilah dalam bahasa Inggris yang mengartikan sebuah alat elektronik kecil dengan berbagai macam fungsi menurut Osland (Juliadi, 2018). Gadget sendiri dapat berupa komputer atau laptop, tablet PC, dan juga telepon seluler atau handphone (Juliadi, 2018).

Dalam survei yang dilakukan oleh

Badan Pusat Statistik (BPS) yang bekerjasama dengan Asosiasi Penyelenggara Jasa Internet Indonesia (APJJII), mencatat bahwa pengguna internet di Indonesia hingga akhir tahun 2013 mencapai 71,19 juta orang, survei ini dilakukan pada 78 kabupaten/kota dan 33 provinsi. Jumlah tersebut mengalami kenaikan dibandingkan dengan hasil survei tahun 2012 yaitu sebanyak 63 juta orang. Itu berarti mengalami kenaikan sebanyak 13 persen, bahkan menurut survei di Sulawesi Utara sudah $100 \%$ menggunakan komputer dan internet. Gadget merupakan barang canggih yang diciptakan dengan berbagai aplikasi yang dapat menyajikan berbagai media berita, jejaring sosial, hobi, bahkan hiburan. Barang canggih ini yang dilihat dari segi harga yang tidak bisa dibilang murah tidak hanya sekedar dijadikan media hiburan semata tapi dengan aplikasi yang terus diperbaharui gadget wajib digunakan oleh orang-orang yang memiliki kepentingan bisnis, atau pengerjaan tugas kuliah dan kantor, akan tetapi pada faktanya gadget tak hanya digunakan oleh orang dewasa atau lanjut usia (22 tahun ke atas), remaja (12-21 tahun), tapi pada anak-anak (7-11 tahun), dan lebih ironisnya lagi gadget digunakan untuk anak usi (3-6 tahun), yang seharusnya belum layak untuk menggunakan gadget (Juliadi, 2018).

Adanya kemajuan teknologi memberikan dampak positif bagi para penggunanya, dengan adanya gadget manusia dapat dengan sangat mudah mencari informasi yang mereka butuhkan juga dapat mempermudah dalam hal pekerjaan atau pun pendidikan dengan adanya aplikasi-aplikasi yang canggih di dalam gadget seperti: internet, sms, jejaring sosial, game, dan lain sebagainya. Meningkatnya penggunaan gadget di Indonesia dikarenakan banyaknya gadget yang dijual dengan harga yang relatif murah yang sudah berbasis android ataupun ios. Namun, semakin berkembangnya teknologi informasi dan komunikasi terdapat dampak negatif dalam penggunaan gadget bila digunakan dengan cara yang salah ataupun menggunakannya secara berlebihan khususnya bagi anak-anak (Simamora, 2016).

Leung

(Yuwanto,

2010)

mendefinisikan kecanduan smartphone sebagai suatu keterikatan dengan smartphone yang disertai kurangnya kontrol serta memiliki dampak negatif bagi anak. Kwon, Kim, Cho, dan Yang (2013) menyebutkan bahwa istilah kecanduan smartphone adalah perilaku keterikatan atau kecanduan terhadap smartphone yang memungkinkan menjadi masalah sosial seperti halnya menarik diri, dan kesulitan dalam performa aktivitas sehari-hari atau sebagai gangguan kontrol impuls terhadap diri seseorang.

Menurut DSM V, Kecanduan Smartphone memiliki 3 kriteria, yaitu:

a. Kriteria A

Periode penggunaan smartphone yang secara signifikan menyebabkan gangguan telah dialami selama tiga bulan dengan kriteria:

1. Berulang kali mengalami kegagalan untuk menolak impuls untuk menggunakan smartphone

\section{Withdrawal}

3. Penggunaan smartphone untuk jangka waktu lebih lama dari yang diinginkan 
4. Keinginan terus-menerus dan / atau usaha yang gagal untuk berhenti atau mengurangi penggunaan smartphone

5. Waktu yang berlebihan dihabiskan untuk menggunakan atau berhenti menggunakan smartphone

6. Melanjutkan penggunaan smartphone yang berlebihan meskipun memiliki pengetahuan tentang masalah fisik atau psikologis yang terus berlanjut atau berulang akibat penggunaan berlebihan dari smartphone

b. Kriteria B

Kerusakan fungsional: dua (atau lebih) dari gejala berikut ini harus ada, yaitu:

1. Penggunaan smartphone yang berlebihan mengakibatkan masalah fisik atau psikologis yang terus berlanjut atau berulang

2. Penggunaan smartphone dalam situasi yang berbahaya secara fisik (misalnya, penggunaan smartphone saat mengemudi atau menyeberang jalan), atau memiliki dampak negatif lainnya pada kehidupan sehari-hari

3. Penggunaan smartphone mengakibatkan gangguan hubungan sosial, prestasi sekolah, atau prestasi kerja

4. Penggunaan smartphone yang berlebihan menyebabkan gangguan subyektif secara signifikan, atau memakan waktu lama

c. Kriteria C

Kriteria pengecualian: Perilaku kedanduan smartphone tidak diperhitungkan dengan obsesif \pm gangguan kompulsif atau dengan gangguan bipolar I.

Aspek-aspek Kecanduan Smartphone yang dikemukakan oleh Lin, dkk. (2014) yaitu, perilaku kompulsif (compulsive behavior), gangguan fungsional (functional impairment), menarik diri (withdrawal), dan toleransi (tolerance).

Folkman dan Lazarus (1984) menyatakan bahwa stress adalah sebuah hubungan antara anak dengan lingkungan yang dinilai oleh anak tersebut sebagai hal yang membebani atau sangat melampaui kemampuan seseorang dan membahayakan kesejahteraannya. Stress juga bisa berarti ketegangan, tekanan batin, dan konflik yang berarti:

a. Satu stimulus yang menegangkan kapasitas-kapasitas (daya) psikologis atau fisiologis dari suatu organisme.

b. Sejenis frustrasi, di mana aktifitas yang terarah pada pencapaian tujuan telah diganggu oleh atau dipersukar, tetapi terhalang-halangi; peristiwa ini biasanya disertai oleh perasaan was-was kuatir dalam percapaian tujuan.

c. Kekuatan yang diterapkan pada suatu sistem, tekanan-tekanan fisik dan psikologis yang dikenakan pada tubuh dan pada pribadi.

d. Satu kondisi ketegangan fisik atau psikologis disebabkan oleh adanya persepsi ketakutan dan kecemasan

Menurut Fieldman (1989), stress adalah suatu proses dalam rangka menilai suatu pristiwa sebagai suatu yang mengancam, menantang, ataupun membahayakan, serta anak merespon peristiwa tersebut baik pada level fisiologis, emosional, kognitif dan tingkah laku. Brecht (Sunaryo, 2002) mengatakan stress merupakan gangguan pada tubuh dan pikiran yang disebabkan oleh tuntutan dan perubahan kehidupan, yang dipengaruhi oleh lingkungan maupun penampilan anak dalam lingkungan. Sedangkan Santrock (2003) menjelaskan bahwa stress adalah respon anak terhadap keadaan atau kejadian yang memicu stress (stressor), yang mengancam dan mengganggu kemampuan seseorang untuk menanganinya (coping). Aspek-aspek yang dikemukakan oleh Sarafino (1994), meliputi aspek reaksi fisiologis, kognisi, emosi, dan perilaku.

Menurut Goeders (2003) anak yang berada dalam masa remaja rentan akan stressor sosial dan peristiwa kehidupan traumatis. Anak yang berada dalam kondisi yang tidak nyaman secara psikologis, akan tetapi situasi tersebut akan berubah menjadi nyaman setelah menggunakan gadget (Yuwanto, 2010). Penggunaan gadget memberikan kenyamanan sebagai reinforcement dan meningkatkan kemungkinan penggunaan gadget menjadi aktivitas sehari-hari sehingga perasaan nyaman ini mengakibatkan anak kehilangan kontrol dalam penggunaan gadget (Song, 2004).

Pada tahun 2015, terdapat survey yang dilakukan oleh The Pew Research Center di Washington mengenai stress dan penggunaan gadget serta sosial media. Data dari Pew Research Center (Smith, 2015) menunjukkan bahwa $46 \%$ dari pengguna smartphone di Amerika Serikat mengaku 
bahwa mereka "Tidak bisa hidup tanpa smartphone". Disamping itu, dalam tiga tahun dari tahun 2011-2014, persentase kepemilikan smartphone di kalangan orang dewasa di Amerika Serikat meningkat pesat dari 35\% menjadi 64\% (Smith, 2015). Selanjutnya, $15 \%$ dari populasi warga Amerika Serikat berumur 18 dan 29 tahun terindikasi ketergantungan pada smartphone guna mengakses internet (Smith, 2015). Penelitian tersebut menemukan bahwa beberapa orang mendapatkan lebih banyak stress saat mereka terlibat dengan gadget atau sosial media. Jadi semakin tinggi waktu penggunaan gadget atau sosial media, semakin banyak pula orang tersebut akan mendapatkan stress. Penelitian ini juga menemukan bahwa perempuan lebih banyak mengalami stress dibandingkan pria, karena perempuan menghabiskan lebih banyak waktu untuk menggunakan gadget dibandingkan dengan pria.

Hasil penelitian Chiu (2014) mengatakan bahwa anak pada umumnya menghadapi stressor akademik, interpersonal, dan keluarga. Ketika anak merasakan tekanan dimana membuat mereka telah kehilangan kontrol dari stress tersebut, seperti kesulitan dalam memahami pelajaran, maka mereka akan mencari pleasure dengan mengakses social communication site tanpa menyadari waktu yang dihabiskan dapat digunakan untuk meningkatkan performa akademik. Hal ini didukung oleh penelitian Junco dan Cotten (2012) yang mengemukakan bahwa penggunaan Facebook dan berkirim pesan saat mengerjakan tugas sekolah berdampak negatif pada hasil evaluasi belajar 263 anak berusia 11-25 tahun yang mengakses Facebook dan berkirim pesan saat mengerjakan tugas sekolah. Demikian juga dalam menghadapi stressor interpersonal, anak yang tidak memiliki kemampuan penyesuaian diri yang baik pada lingkunngan baru cenderung memiliki stress yang tinggi (Tri dan Bashori, 2013). Tingginya stress mengakibatkan anak menghindar ketika berinteraksi di kehidupan nyata akibatnya anak mengabaikan kehidupan nyata dan interaksi secara online meningkat (Whang, Lee, \& Chang, 2003). Gadget memberikan sarana yang nyaman bagi anak sehingga tidak harus berinteraksi, bersosialisasi, maupun menunjukkan diri di kehidupan nyata (Jin \& Park, 2009). Menurut Song, dkk. (2004), penggunaan gadget memberikan kenyamanan sebagai reinforcement dan meningkatkan kemungkinan penggunaan gadget menjadi aktivitas sehari-hari sehingga perasaan nyaman ini mengakibatkan anak kehilangan kontrol dalam penggunaan gadget dan menjadi kecanduan.

\section{METODE PENELITIAN}

Kegiatan pengabdian kepada masyarakat ini menggunakan metode komunikasi dua arah vertikal hal ini dilakukan dengan maksud memberikan informasi tepat guna bagi para peserta, yang pada kali ini adalah para siswa/i kelas X dan kelas XI SMA Katolik Santo Petrus Kanisius, Kalimantan Tengah.

Manfaat dari kelebihan dari komunikasi dua arah adalah sebagai berikut:

- Adanya dialog antara komunikator dengan komunikan, sehingga menimbulkan kepuasan diantara kedua belah pihak,

- Informasi yang diterima menjadi lebih jelas, lebih akurat dan lebih tepat, karena dapat diperoleh langsung penjelasanya.

- Komunikan bebas untuk bertanya mengenai informasi yang diberikan pada sesi tanya jawab kepada komunikator agar dapat menghindari kesalahpahaman dan mendapatkan informasi yang lebih jelas,

Rangkaian acara kegiatan ini dimulai pada hari Jumat, 16 April 2021 pada PK 13.00-15.00 dengan metode daring via google meet, Sesi awal dimulai dengan pegisian pretest mengenai materi kecanduan gadget agar dapat menguji tingkatan pengetahuan peserta terhadap materi yang akan disampaikan. Setelah itu dilanjutkan dengan membagikan penjelasan mengenai materi kecanduan gadget. Pada sesi selanjutnya para siswa disediakan waktu untuk tanya jawab dan diskusi. Sesi selanjutnya, para siswa diajak untuk bermain games untuk memecah 
kejenuhan para siswa/I. Sesi diakhiri dengan pengisian posttest dan form evaluasi kegiatan.

Berikut adalah rentetan kegiatan PKM Online yang dilaksanakan Di SMA Katolik St. Petrus Kanisius, Palangkaraya, Kalimantan Tengah dengan teman "Mengenal Bahaya Adiksi Gadget dan Cara Mengatasinya", kegiatan ini dilaksanakan pada :

\section{Hari : Jumat, 16 April 2020}

Pukul : $13.00 \mathrm{WIB}$ - selesai

Kegaiatan ini dilaksanakan dalam 1
(satu) hari melalui online dengan menggunakan Google Meet, dan dihadiri oleh 16 peserta dari kelas X-MIA1 dan X-MIA2, SMA Katolik St. Petrus Kanisius, Palangkaraya, Kalimantan Tengah. Kemudian juga terdiri dari 8 mahasiswa dan 3 dosen pendamping dari Universitas Bunda Mulia, Ancol, Jakarta.

Sesuai dengan rundown acara, kegiatan dimulai pada pukul 13.00 WIB, dengan catatan 15 menit sebelum acara peserta diwajibkan untuk bergabung dalam google meet dengan link yang sudah dibagikan kepada peserta. Setelah peserta sudah bergabung didalam google meet tersebut, peserta diberi arahan dengan mengisi link presensi dan juga soal pre-test diawal kegiatan, yang ditampilkan pada share screen dan juga pada kolom chat yang sudah disediakan oleh pelaksana. Setelah semua peserta sudah mengisi link presensi dan juga soal pre-test, maka kegiatanpun akan dimulai. Kegiatan PKM Online ini diawali dengan mc yang membuka acara, kemudian setelah mc membuka rangkaian kegaiatan, mc meminta salah satu peserta untuk memimpin doa, sebelum memulai kegiatan. Setelah doa yang dipimpim peserta, dilanjutkan dengan kata sambutan oleh dosen pembina yaitu Ibu Devi Jatmika, S.Psi., MMP. Ibu Devi juga menyelingi kegiatan disela-sela beliau memberikan kata sambutan, kegaiatan tersebut Ibu Devi meminta peserta untuk mengakses link slido.com, yang mana $\mathrm{Bu}$ Devi memberikan pertanyaan-pertanyaan mengenai adiksi gadget kepada peserta PKM Online, dengan pertanyaan sebagai berikut :

1) Aplikasi apa yang sering kamu buka saat bermain internet?
2) Seberapa besar bermain HP dengan aktivitas sehari-hari?

3) Berapa lama kamu bermain Hp setiap hari?

4) Apakah sulit bagi kamu untuk berhenti bermain HP, jika sudah memulai?

Setelah mengisi beberapa pertanyaan tersebut, Bu Devi menyimpulkan bahwa ratarata perserta merasa kesulitan untuk berhenti bermain handphone, jika sudah memulai dengan peresentase $85 \%$. Kegiatan selanjutnya setelah mendengar kata sambutan dan juga menjawab beberapa pertanyaan dari $\mathrm{Bu}$ Devi, yaitu pemapara materi PKM Online yang dipresentasikan oleh Theresia Finda Kusuma (13180009) dan Alfina Damayanti (13180003), pemaparan materi ini sendiri berlangsung selama 35-40 menit.

Selesai pemaparan materi oleh pelaksana, kegiatan selanjutnya yaitu sesi tanya jawab, yang mana peserta diberikan kesempatan untuk bertanya mengenai materi yang sudah diberikan. Pada sesi tanya jawab ini dipandu langsung oleh 2 (dua) dosen pembinbing yaitu Ibu Mutiara Mirah Yunita, S.Psi., M.Psi. dan Bapak Teguh Lesmana, S.Psi., M.Psi. Sesi tanya jawab ini berlangsung sekitar 15-20 menit.

Selesainya sesi tanya jawab dari peserta, kegiatan selanjutnya yaitu game, game disini dipandu oleh Melinda Sulistiyani (13180024) dan Serliana (13180032) game yang digunakan oleh pelaksana yaitu game online yang bernama Gartic.io. Gartic.io ini merupakan game tebak gambar, yang mana salah satu pemain akan memberikan petunjuk dengan menggambar sesuai dengan pilihan petunjuk yang dia inginkan dan pemain lainnya menjawab sesuai dengan apa yang digambarkan oleh pemain yang memberi petunjuk tersebut. Game ini berlangung 10 menit, dan semua peserta dan beberapa pelaksana ikut andil juga didalam pemainan tembak gambar ini.

Setelah selesai bermain game tebak gambar, selanjutnya mc mengambil alih kegiatan dan mengumumkan untuk para peserta mengisi link presensi 2 dan juga soal post-test. Setelah mengisi link presensi 2 dan juga soal post-test, peserta dipersilahkan untuk meninggalkan google meet. 


\section{HASIL DAN PEMBAHASAN}

Selama pengabdian ini dijelaskan bahwa gadget diciptakan untuk mempermudah pekerjaan manusia, tapi manusia menghabiskan lebih banyak waktu untuk menggunakan gadget. Berdasarkan Survey The Paw Research Center di Washington (2015), beberapa orang mendapatkan lebih banyak stress saat mereka lebih banyak terlibat dengan gadget / social media. Sehingga, dapat dikatakan bahwa gadget maupun social media yang memberikan dampak positif bagi manusia dapat juga memberikan dampak yang negatif seperti gejala psikologis maupun fisik, terlebih jika adanya penggunaan secara berlebih.

Di dalam pengabdian kepada masyarakat yang telah dilakukan pada tanggal 16 April 2021 kemarin, telah diberikan formulir pre-test untuk diisi oleh siswa/i dari SMA Katolik Santo Petrus Kanisius sebelum acara dimulai. Berdasarkan jawaban dari siswa/i, kebanyakan dari mereka telah mampu memahami dengan cukup baik mengenai dampak negatif dan juga bahaya dari penggunaan gawai secara berlebihan.

Setelah mengikuti kegiatan pengabdian yang dilakukan sampai selesai, berdasarkan perbandingan antara pre-test dan post-test, beberapa siswa/i telah memiliki pengetahuan dan pemahaman yang bertambah, yang dapat dilihat dari cara mereka menjawab pertanyaan yang tersedia menggunakan pengembangan pengetahuan yang telah diperoleh dari kegiatan pengabdian. Berikut adalah tabel perbandingan hasil dari pre-test dan posttest.

Table 1 Perbandingan Hasil Pretest dan Posttest dari para siswa SMA Katolik Santo Petrus Kanisius Yang Mengikuti Pelatihan

\begin{tabular}{|l|c|c|}
\hline \multicolumn{1}{|c|}{ Inisial } & Pre-test & Post-test \\
\hline OA & 75 & 100 \\
\hline JEP & 75 & 75 \\
\hline
\end{tabular}

\begin{tabular}{|l|c|c|}
\hline CEL & 100 & 100 \\
\hline YM & 75 & 75 \\
\hline RS & 75 & 75 \\
\hline CKH & 50 & 75 \\
\hline RLB & 100 & 100 \\
\hline AG & 75 & 100 \\
\hline IK & 100 & 50 \\
\hline BJ & 100 & 100 \\
\hline LN & 100 & 100 \\
\hline EFS & 100 & 100 \\
\hline SLSL & 50 & 50 \\
\hline CH & 75 & 75 \\
\hline Rata-rata & 82.14 & 83.92 \\
\hline
\end{tabular}

Pada pre-test dan juga post-test terdapat 4 butir soal yang disediakan, dimana setiap 1 soal telah diberikan bobot 25 jika benar. Dari tabel, dapat dilihat pula bahwa selama pre-test, sudah banyak siswa/i yang mendapatkan nilai 100 atas jawaban mereka, yakni 6 orang. Sementara pada tahap posttest, dari 14 siswa/i yang menghadiri acara, terdapat 7 orang yang mendapatkan nilai 100 atas jawaban mereka. Hal ini berarti bahwa $1,78 \%$ siswa/i telah mampu menyerap dan mengembangkan informasi-informasi yang diberikan pada saat kegiatan pengabdian.

Hasil evaluasi bagi pembicara pada pengabdian ini pun mendapatkan tanggapan yang baik dari siswa/i SMA Katolik Santo Petrus Kanisius, dari hasil kemampuan atau penguasaan terhadap materi oleh narasumber pun sudah baik, kemampuan dalam menyampaikan materi oleh narasumber sudah sangat baik, kemampuan menggunakan metode yang tepat dengan materi oleh narasumber sudah baik, serta kemampuan 
dalam menjawab pertanyaan peserta oleh narasumber juga sudah baik. Sehingga, dapat terciptalah suasana yang baik dan nyaman yang mendukung kegiatan bagi para siswa/i selama penyampaian materi ini.

Secara keseluruhan, dapat dikatakan bahwa kegiatan pengabdian kepada masyarakat yang bertajuk pengaruh gawai terhadap stress ini telah berhasil dilakukan dengan memperoleh umpan balik yang baik dan positif dari para siswa/i.

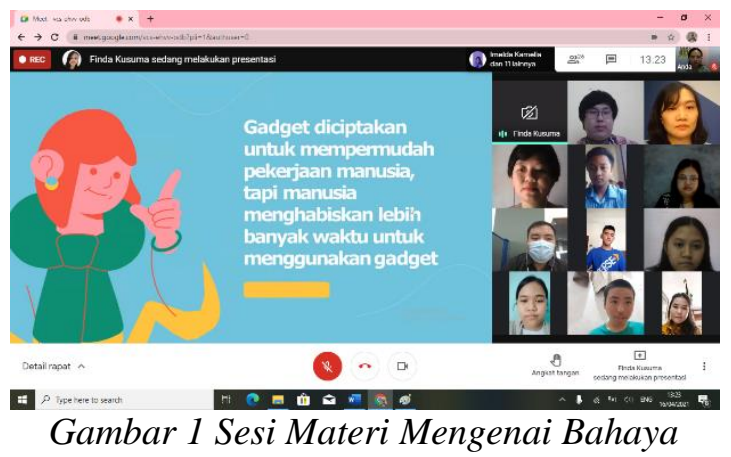

Gadget Yang Dibawakan oleh Narasumber

Ibu Mutiara Mirah Yunita dan Bapak Teguh

Lesmana

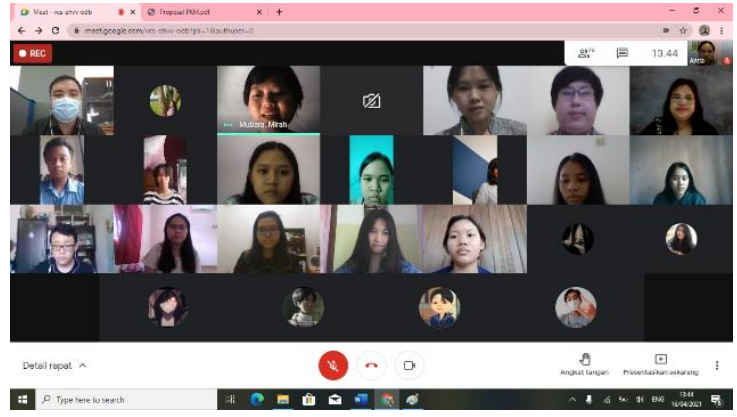

Gambar 2 Sesi Tanya Jawab Mengenai

Bahaya Gadget Yang Dipandu Oleh

Narasumber Ibu Devi Jatmika

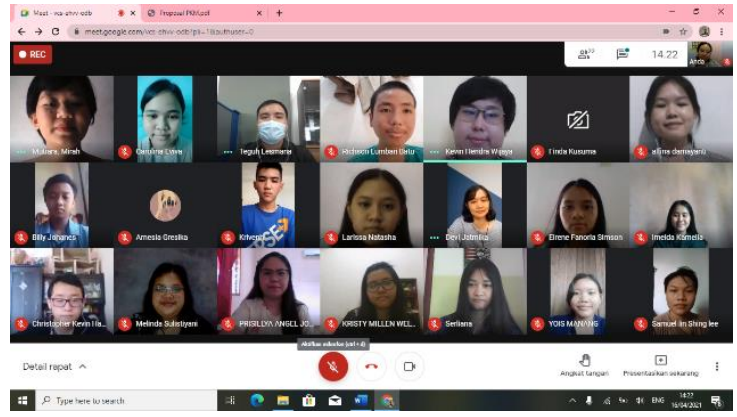

Gambar 3 Sesi Foto Bersama Sebagai Penutup Acara Bersama Dengan Peserta
Siswa SMA Katolik Santo Petrus Kanisius Yang Mengikuti Pelatihan

\section{SIMPULAN}

Setelah diadakannya kegiatan ini, ada beberapa saran yang dapat kami sampaikan :

1. Pengabdian kepada masyarakat dilakukan kembali untuk meningkatkan pengetahuan masyarakat luas.

2. Melakukan pengabdian kepada masyarakat dilakukan secara tatap muka dikemudian hari.

3. Menargetkan peserta lain yang juga membutuhkan informasi lebih.

4. Menggali topik-topik menarik lainnya sebagai bahan pengabdian kepada masyarakat selanjutnya.

Gawai/gadget merupakan sesuatu yang sudah erat dengan manusia di masa saat ini, gawai memiliki dampak negatif dan dampak positif seperti orang-orang dapat terhubung meskipun tidak bertatap muka, membantu mempermudah hidup meskipun demikian gawai juga memiliki dampak negatif yang cukup besar bagi seseorang seperti stress dan kurang nya harga diri .Dengan diadakannya pengabdian kepada masyarakat dengan tema pengaruh gawai terhadap stress, diharapkan dapat memberikan pengetahuan dan wawasan baru mengenai dampak penggunaan gawai terhadap kehidupan sehari-hari sehingga siswasiswi dapat bijak dan tepat dalam menggunakan gawai. Dan kedepannya diharapkan membantu siswa-siswi menjadi lebih produktif dalam aktivitas sehari-hari.

\section{DAFTAR PUSTAKA}

Amalia, F.R. \& Hamid, Y.S.A. 2020. Adiksi Smartphone, Kesehatan Mental Anak, dan Peranan Pola 
Asuh. Jurnal Ilmu Keperawatan Jiwa, 3(2). 221-240.

Badan Pusat Statistik. 2019. Statistik Telekomunikasi Indonesia.

Jakarta: Badan Pusat Statistik Indonesia.

Marpaung, J. (2018). PENGARUH PENGGUNAAN GADGET DALAM KEHIDUPAN. Jurnal KOPASTA, 5 (2), 55-64. Doi:

https://doi.org/10.33373/kop.v5i2. 1521

Rashid, I., Soren, K. 2019. Offline, Free Your Mind from Smartphone and Social Media Stress. Great Britain: TJ International Ltd.

Rini, K.M. \& Huriah, T. 2020. Prevalensi dan Dampak KEcanduan Gadget pada Remaja: Literature Review. Jurnal Keperawatan Muhammadiyah 5(1). 185-194.

Simangunsong, S. Dian, R.S. 2017. HUBUNGAN STRES DAN KECANDUAN SMARTPHONE PADA SISWA KELAS X SMA NEGERI 5 SURAKARTA. Jurnal Empati, 6 (4), 52-66.

\section{WEBSITE}

https://kominfo.go.id/index.php/content/d etail/3834/Siaran+Pers+No.+17PIH-KOMINFO-22014+tentang+Riset+Kominfo+da n+UNICEF+Mengenai+Perilaku+ Anak+dan+Remaja+Dalam+Meng gunakan+Internet+/0/siaran_pers 